\title{
Long-term effects of climate and land-use change on larch budmoth outbreaks in the French Alps
}

\author{
Giovanna Battipagliai, ${ }^{1,2,3}$, Ulf Büntgen ${ }^{4,5,6}$, Shane P. J. McCloskey ${ }^{2}$, \\ Olivier Blarquez ${ }^{1,2,7}$, Nicole Denis ${ }^{2}$, Laure Paradis ${ }^{2}$, Benoit Brossier ${ }^{2}$, \\ Thomas Fournier ${ }^{1,2}$, Christopher Carcaillet ${ }^{1,2}$ \\ ${ }^{1}$ Paleoenvironments and Chronoecology (PALECO-EPHE), Ecole Pratique des Hautes Etudes, Institut de Botanique, \\ 163 rue Broussonet, 34090 Montpellier, France \\ ${ }^{2}$ Centre for Bio-Archaeology and Ecology (CNRS UMR5059), University of Montpellier 2, Institut de Botanique, \\ 163 rue Broussonet, 34090 Montpellier, France \\ ${ }^{3}$ Department of Environmental, Biological and Pharmaceutical Sciences and Technologies (Di.S.T.A.Bi.F.), \\ Second University of Naples, Via Vivaldi 43, 81100 Caserta, Italy \\ ${ }^{4}$ Swiss Federal Research Institute WSL, 8903 Birmensdorf, Switzerland \\ ${ }^{5}$ Oeschger Centre for Climate Change Research, University of Bern, 3012 Bern, Switzerland \\ ${ }^{6}$ Global Change Research Centre AS CR, v.v.i., 60300 Brno, Czech Republic \\ ${ }^{7}$ Centre d'étude de la forêt, Université du Québec à Montréal, C.P. 8888, Montréal, Québec H3C 3P8, Canada
}

\begin{abstract}
The intensity of cyclic larch budmoth (Zeiraphera diniana Guenée; LBM) outbreaks across the European Alps has been reported to have weakened since the early 1980s. In addition to a warmer climate, changes in land-use cover over modern and historical times may have affected the LBM system. Here, we present tree-ring-based reconstructions of LBM outbreaks from a mixed subalpine larch-pine forest in the French Alps for the period 1700-2010. Temporal variation in LBM outbreak severity was mainly driven by land-use changes, including varying forest structure and species composition. Human population pressure and associated resource demands for fuel wood and construction timber not only resulted in a reduction of larch and subsequent suppression of pine, but also supported an overall grassland expansion for livestock. Superimposed on modern land abandonment and pine re-colonization is a strong warming trend, which may also contribute to the observed late 20th-century weakening of Alpine-wide cyclic LBM outbreaks. Our results suggest that a complex interplay of different factors triggered less synchronized LBM outbreaks at broader scales, with overall significantly lower intensities at local scales.
\end{abstract}

KEY WORDS: Zeiraphera diniana $\cdot$ Tree rings $\cdot$ Climate change $\cdot$ Land use/cover change $\cdot$ Forest structure $\cdot$ Tree composition

\section{INTRODUCTION}

Biological disturbances are an integral component of plant communities (White \& Pickett 1985, Johnson \& Miyanishi 2007). In forest ecosystems, biodisturbances, such as insect outbreaks, play an important role in shaping forest composition, structure and dynamics (Morin et al. 2007). Long-term records of insect outbreaks show that the duration and severity of such events can be influenced by land management, together with aspects of fire suppression (Blais 1983, Mitchell 1990), as well as landscape fragmentation (Roland 1993, Radeloff et al. 2000, Wood et al. 2010). Furthermore, population outbreaks of the larch budmoth (Zeiraphera diniana Guenée; LBM) cause defoliation, and thus inhibit ring width forma- 
tion in the moth's main subalpine host tree, the European larch (Larix decidua Mill), widespread between $\sim 800$ and $2300 \mathrm{~m}$ a.s.l. (Bernetti 1998). The LBM is a Holarctic insect characterized by regular large-scale population outbreaks (Baltensweiler \& Rubli 1999); such outbreaks seem to be closely related to the prevailing ecological site conditions and synoptic-scale climate fluctuations (Baltensweiler et al. 2008). Until the 1970s, LBM had mass outbreaks every 8-9 yr with a regularity that has not been adequately explained (Büntgen et al. 2009). Certain factors have been hypothesized, such as changes in densitydependent factors (Fischlin \& Baltensweiler 1979, Bjornstad et al. 2002, Turchin et al. 2003, Johnson et al. 2004). A decline in the intensity of LBM outbreaks and a lack of spatial synchrony have been observed across the European Alps since 1981 (Baltensweiler 1993). A possible reason for this and comparable collapses of population cycles might indeed be direct and/or indirect effects of global warming (Esper et al. 2007, Kress et al. 2009, Johnson et al. 2010). However, it has been demonstrated that outbreaks of the same insect species may respond differently to warming and dryings trends in different parts of the insect geographic distribution range (Thomson et al. 1984, Swetnam \& Lynch 1993), and that insect dynamics may be influenced by more than one environmental driver (Cappuccino \& Price 1995, Simard et al. 2012). In this regard, possible effects on LBM dynamics and its outbreaks associated with land-use changes that alter the land cover have, to our knowledge, never been properly considered. The profound landscape transformation in the European Alps, particularly during the second half of the 20th century in France and Italy (Motta \& Garbarino 2003, Tasser et al. 2009), has the potential to alter and may even disrupt the cyclic behavior of the LBM system on various spatiotemporal scales. Forest dynamics and composition have been severely influenced by societal activities (Motta \& Nola 2001, Risch et al. 2003), with larch having been favored over Arolla pine (Pinus cembra L.) for several decades because it was more compatible with grazing activities and useful for domestic uses (i.e. fuel wood, building material). Recently, with land-use abandonment, $P$. cembra has begun to re-establish (Motta \& Nola 2001, Holtmeier 2003) and larch regeneration has decreased (Chauchard et al. 2010).

Based on the fact that forest cover has changed in area, pattern and perhaps in composition, and that LBM is closely associated with certain trees, it would be useful to determine whether land-use abandonment might have influenced the dynamics of LBM outbreaks. This would be of great importance for future decadal projections of land management and natural resources (Sala et al. 2000). Indeed, the direct effect of climate and land use on LBM and larch ecology is not yet understood, and interactions between them represent a large uncertainty in projections of future ecological change in the Alps. The influence of land-use change on ecological processes is a solidly established concept (Watt 1947), but quantification of those effects remains an issue, due to the complexity of the factors involved (Peterson \& Parker 1998) and the difficulty of conducting large-scale experiments over long temporal scales. Thus, more research is clearly needed to make reliable predictions about not only the climate system and the insect biology, but also the interactions between climate change and landuse change, insect population dynamics and forest responses.

Here, we use tree-ring width (TRW) measurements to detect and reconstruct historical LBM outbreaks in 5 mixed forests of $L$. decidua (hereafter larch) and P. cembra (pine) all situated in a French Alpine valley. We aim to: (1) analyze changes in outbreak frequency over the last 3 centuries, and (2) understand how dynamics of the LBM system are related to changes in climate and/or land use. Reconstructed LBM outbreak patterns are therefore compared with temperature and precipitation variability during the past 3 centuries, as well as with modifications in both larch and pine forest structure and composition. Although based on a local-scale study, the complex interplay of natural and social drivers on the LBM system is presented and discussed with special emphasis on past, present and projected broader land-cover changes in the French Alps.

\section{MATERIALS AND METHODS}

\subsection{Site characteristics and sampling design}

The Maurienne Valley, Savoy, France, is a typical arc-shaped Alpine valley located along the border between France and Italy, and is dominated by mixed larch-Arolla pine forests in the subalpine. The treeline is located between 2350 and $2400 \mathrm{~m}$ a.s.l., depending on slope and aspect. We selected 5 sampling sites in order to cover the whole upper valley (from west to east): Orgère (ORG, 45 $13^{\prime} 27^{\prime \prime} \mathrm{N}$, $\left.6^{\circ} 40^{\prime} 33^{\prime \prime} \mathrm{E}\right)$, on a south-facing slope, and on northfacing slopes, Avrieux-Arlette (ARL, 45 $13^{\prime} 10^{\prime \prime} \mathrm{N}$, $\left.6^{\circ} 42^{\prime} 55^{\prime \prime} \mathrm{E}\right)$, Bramans val d'Ambin (AMB, 45 $13^{\prime} 22^{\prime \prime} \mathrm{N}$, 


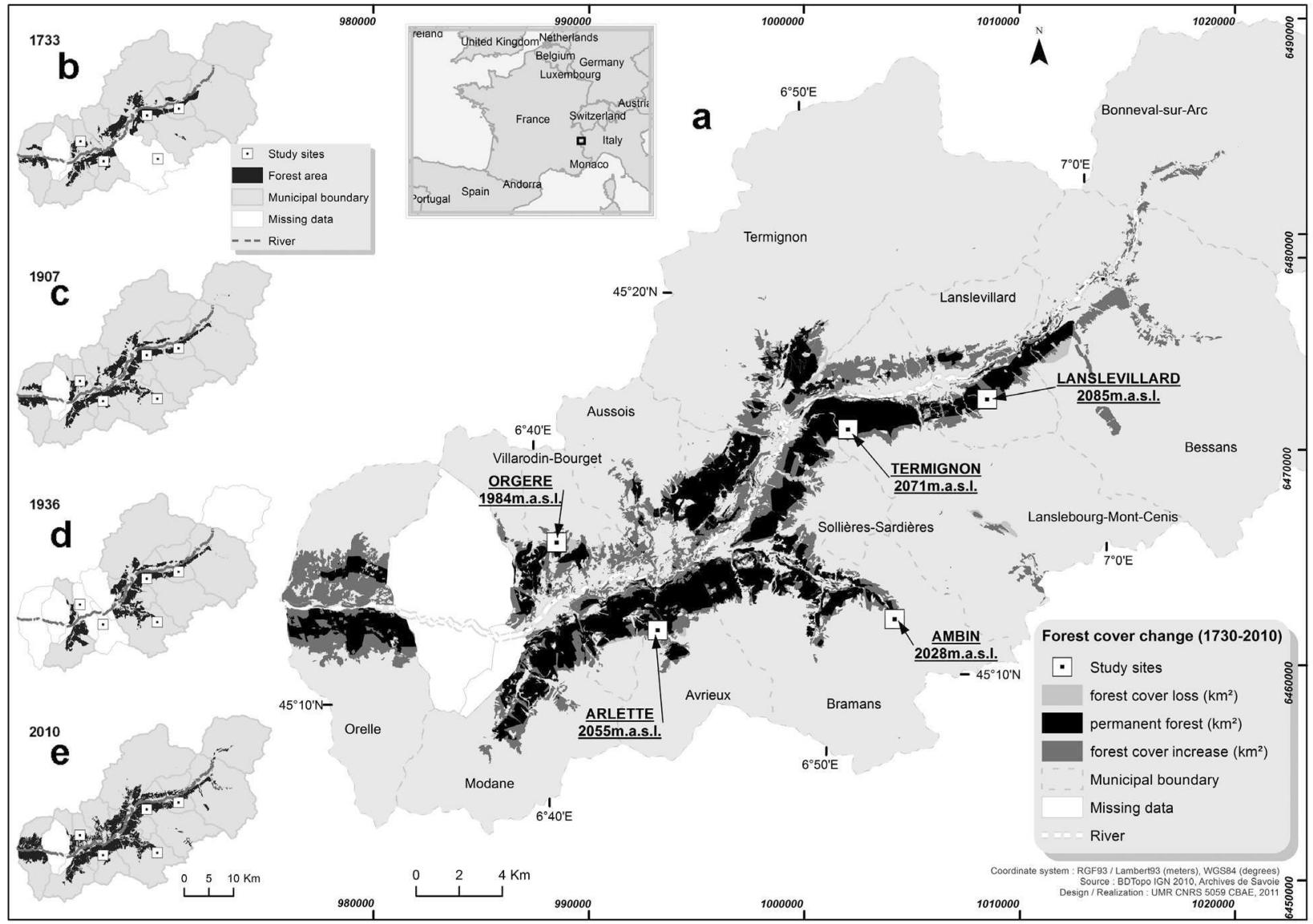

Fig. 1. (a) Upper Maurienne Valley with the sampling sites (white circles) and area of forest cover change $\left(\mathrm{km}^{2}\right)$ in the period 1728-2010. In particular, permanent forests (black area), forest cover loss (light gray area) and the increase in forest cover (mid-gray area) are reported: (b) forest area $\left(\mathrm{km}^{2}\right)$ in 1728-1738 (source Mappe Sarde), (c) forest area $\left(\mathrm{km}^{2}\right)$ in 1850-1895 (source Premier cadastre français), (d) forest area $\left(\mathrm{km}^{2}\right)$ in 1927-1939 (source Cadastre rénové) and (e) forest area $\left(\mathrm{km}^{2}\right)$ in 2010. White areas indicate that data are missing or not verified

$\left.6^{\circ} 46^{\prime} 35^{\prime \prime} \mathrm{E}\right)$, Termignon (TER, $\left.45^{\circ} 16^{\prime} 37^{\prime \prime} \mathrm{N}, 6^{\circ} 48^{\prime} 59^{\prime \prime} \mathrm{E}\right)$ and Lanslevillard (LAN, 45 $17^{\prime} 25^{\prime \prime} \mathrm{N}, 6^{\circ} 54^{\prime} 34^{\prime \prime} \mathrm{E}$ ) (see Fig. 1 for details).

In fall 2009 and spring 2010, 10 mixed larch-pine plots (plot size $=400 \mathrm{~m}^{2}$ ) were designed along an altitudinal gradient between 1700 and $2000 \mathrm{~m}$ a.s.l., in which all trees (pine and larch) were sampled to determine their individual growth rates and ages, as well as stand age structure and forest recruitment history. A tree was considered when its diameter $(\varnothing)$ was $>5 \mathrm{~cm}$ at $30 \mathrm{~cm}$ height $(h)$; a sapling when $\varnothing<5 \mathrm{~cm}$ at $h=30 \mathrm{~cm}$; a seedling when $h \leq 30 \mathrm{~cm}$. The age of trees, determined by taking one core per tree, was assessed after correction of the age-at$30 \mathrm{~cm}$ using an allometric equation providing the number of years to reach the coring height (Motta et al. 2006, Genries et al. 2009). This procedure is based on the assumption that the harvested saplings grew at the same rate as the initial growth rate of the mature trees from which the cores were obtained. Based on height-age analysis, the age to reach coring height was estimated to be $10 \pm 3 \mathrm{yr}$ ( $\mathrm{n}=665, \mathrm{r}=0.62, \mathrm{p}<0.001$ ) for larch, and $13 \pm 5 \mathrm{yr}$ ( $\mathrm{n}=144, \mathrm{r}=0.65, \mathrm{p}<0.001$ ) for Arolla pine (Genries et al. 2009). Since the procedures used for age estimation can introduce errors into subsequent analyses, age structure was constructed for 10 yr classes to account for these errors.

Two cores per tree were taken at breast height ( $1.3 \mathrm{~m}$ above surface) from $20-27$ individuals of larch and pine trees per site to guarantee the subsequent development of robust tree-ring chronologies. Pine is normally a non-host species for the common dark form of LBM (Baltensweiler 1993, Nola et al. 2006), which can be a valuable reference species to help disentangle the effect of insect defoliation on TRW from that of adverse climatic conditions (Dormont et al. 2006, Büntgen et al. 2009). 


\subsection{Sample preparation and chronology development}

All core samples were air dried, glued onto wood supports, and sanded to enhance ring boundaries. Ring-width measurements were performed with a resolution of $0.01 \mathrm{~mm}$, using LINTAB equipment (Frank Rinn, Heidelberg, Germany), and subsequently analyzed with the TSAP software package. After visual cross-dating to identify missing rings, common marker years and ring width patterns were assessed according to Gleichläufigkeit, a statistical measure of the year-to-year agreement between the interval trends of the chronologies based upon the sign of agreement (Schweingruber 1988), and a Student's $t$-test, which determines the degree of correlation between curves. Cross-dating of all the tree-ring series was then verified using the COFECHA program (Holmes 1993), which assesses the quality of cross-dating and measurement accuracy of tree-ring series using the segmented time-series correlation technique. To remove the biological age trend and facilitate examination of climatic extremes in the context of adjacent years and decades, the TRW data were detrended using first a negative exponential or linear function, and $30 \mathrm{yr}$ cubic smoothing splines as a second option by means of ARSTAN software (Cook 1985). This rigorous detrending was previously used in papers to identify LBM outbreaks (Speer et al. 2001, Nola et al. 2006, Paritsis et al. 2009) and to emphasize high-frequency year-to-year variability in the remaining chronologies (Battipaglia et al. 2010). Afterwards, an autoregressive model was applied to remove the autocorrelation structure with the previous year ring width, resulting in white-noise time series (Biondi \& Swetnam 1987). Individual series within each site were averaged with a robust (biweight) estimation of the mean. The expressed population signal (EPS) was calculated within each site to indicate the level of coherence of the constructed chronology, and how it portrays the hypothetical perfect population chronology.

\subsection{Growth-climate response analyses and outbreak detection}

Correlations between the TRW chronologies and climate variables were calculated for the period 1700-2000 to identify the dominant climate controls of ring formation. High-resolution $0.5^{\circ} \times 0.5^{\circ}$ grids (Casty et al. 2005) of monthly temperature means and precipitation were used for growth-climate re- sponse analyses. Correlation coefficients were calculated separately between each month and seasonwinter (January, February, March), spring (April, May), summer (June, July, August), autumn (from September to December) - and temperature and precipitation, using bootstrapped correlation analyses for significance testing ( $p<0.05$; Guiot 1991). To quantify temporal changes in the relationship between climate and TRW, we additionally calculated moving correlations over $40 \mathrm{yr}$ time windows, thus producing a time series of bootstrapped correlation coefficients on a monthly and seasonal basis (Biondi \& Waikul 2004, Kress et al. 2009). However, only the significant correlations were discussed and displayed.

Three different methods were applied to identify LBM outbreaks: (1) the pointer year method, where each tentative outbreak year must be associated with a $>50 \%$ growth reduction compared with the 6 neighboring rings (Paritsis et al. 2009); (2) comparisons of host (larch) and non-host species (pine), where the outbreaks were detected as a decrease in the growth of individual host trees without a corresponding decrease in the non-host species (Büntgen et al. 2009); and (3) identification of characteristic years or periods that meet or exceed some assigned parameter, such as ring-width index (RWI) $\geq 0.85$ standard deviations $(\sigma)$ below the mean RWI (ca. the smallest 20th percentile) and the RWI for the 1st year of the inferred outbreak $\leq 60 \%$ of the previous year (Nola et al. 2006). An outbreak is identified when the 3 methods agree, in the case of larch chronology, and when methods (1) and (3) agree, in the case of pine chronology. Methods (2) and (3) were assessed using the OUTBREAK program (R. L. Holmes and T. W. Swetnam, unpubl. manual [on file at Laboratory of Tree-Ring Research, University of Arizona]; see also Speer et al. 2001). This program generally compares the host chronologies with non-host chronologies; the climate signals are removed through subtraction of the non-host index chronology and the occurrence of outbreaks events is recorded. For Method (3), we ran OUTBREAK separately for larch and pine, and considered them both to be possible host species. In this case, the individual chronologies were analyzed to identify the growth reduction corresponding to the following parameters: (1) RWI $\geq 0.85 \sigma$ below the mean RWI and (2) RWI for the first year of the inferred outbreak $\leq 60 \%$ of the previous year.

LBM outbreak reconstruction was initially performed at the site level. The site chronologies were then aggregated into a regional composite time series of outbreak events for the whole study area. To avoid spurious interpretation of past outbreak frequency 
due to the low sample size, we started our analysis of the composite time series in 1700 (when at least 50\% of the total sampled trees were included in the total chronology). Only years at each site with $>25 \%$ of affected series were regarded as outbreaks (Nola et al. 2006, Büntgen et al. 2009). See Table 1 for the characteristics of reconstructed LBM attacks of larch and pine. Frequency, percentage of affected trees and growth reduction distribution were transformed and fitted by locally weighted polynomial regression (LOWESS; Cleveland 1979) smoothing with a $50 \mathrm{yr}$ time window. The statistical significance of switches in event frequencies was determined where trends exceed $2 \sigma$ away from the long-term mean.

Superposed epoch analysis (SEA; Swetnam \& Betancourt 1990) was further applied to test the statistical significance of the associations between environmental events (outbreaks or climate) and tree-ring growth. SEA was conducted by taking into account, for each outbreak, the first year of the attack and the 3 years before and after the selected year; it was performed using the EVENT program (R. L. Holmes and T. W. Swetnam, on file at the Laboratory of Tree-Ring Research, University of Arizona). Statistical significance was determined by a bootstrap method in which years are selected randomly, and expected mean values of climate conditions are calculated for the entire period of analysis. We performed SEA for climate data by 1, 2 and 3 month seasons, and annual time periods, but only results that are statistically significant and consistent across different data arrangements are shown. Moreover, we used singular spectrum analysis (SSA) to assess possible oscillatory behavior and changing temporal patterns of reconstructed LBM along the chronology for different periods. It is a nonparametric method for analyzing time series similar to principal components analysis (Vautard \& Ghil 1989). SSA enables the user to evaluate changing periodic behavior in a single time series by extracting pairs of 'reconstructed components' or 'waveforms', which represent the dominant periodic modes of the time series. SSA was applied to the tree growth increment data and was performed using the SSA program (J. A. Boninsegna and R. L. Holmes, on file at the Laboratory of TreeRing Research, University of Arizona).

\subsection{Historical information}

Antique maps, along with additional GIS data and reports, were used to estimate the change in forest cover between different time periods. In particular, we used Mappe Sarde, first land register of the Duchy of Savoy, Kingdom of Sardinia (established in 17281738), Premier cadastre français (est. 1850-1895), Cadastre rénové (est. 1927-1939), the phytosociological map (Bartoli 1996), Corine Land Cover (2000) and the database BD topo IGN (2010).

The antique maps (data source: www.archinoe.net/ cg73v2/cadastre.php) were scanned, rasterized, georeferenced and vectorized into a GIS system (ESRI ArcInfo 9.3). The maps were further enhanced by rubber sheeting, which spatially warps the data to fit with more accurate modern maps (Balletti 2000, Niederoest 2002). See Table 2 for details on the maps; original map photos are available in Figs. S1 and S2 in the Supplement at www.int-res.com/ articles/suppl/c062p001_supp.pdf.

The rubber sheeting process aims to: (1) identify control points on historical maps and on the presentday one (we used as a reference the BD topo IGN 2010; the unmoved temporal geo-features are set as the control points, such as important settlements, rivers and mountains); (2) perform quality control checks on the spatialized database (metadata are loaded into GIS from the database software program Access); and (3) obtain an affine transformation to change the coordinate system origin and to remove possible geometric distortion (Ghilani \& Wolf 2006).

The digital plot maps were merged into a master coverage illustrating the subdivision history across the study area. The plots were used to calculate the area covered by permanent forests during the different map periods and the possible spatial error due to differences in map scales and the georeferencing methods used. The quality of the historical maps, in terms of completeness, integrity and correctness, was high for all the municipalities except Bramans, where the control points did not perfectly overlap (white zone in Fig. 1). Further, because it is well known that altitude plays an important role in the interaction between climate and LBM outbreak patterns (Baltensweiler \& Rubli 1999, Johnson et al. 2010, Daux et al. 2011), we verified that most of the change in forest cover occurred in subalpine forest at an altitude between 1700 and $2000 \mathrm{~m}$ a.s.l. (Fig. S3 in the Supplement at www.int-res.com/articles/suppl/c062p001_ supp.pdf), which is considered the optimal zone for larch defoliation (Baltensweiler et al. 2008).

Human population and livestock inventories were obtained for each municipality over the last $260 \mathrm{yr}$. The numbers of permanent inhabitants in the villages closest to the study site were obtained from demographic databases (http://cassini.ehess.fr), from the Archives Départementales de Savoie (www. 
savoie-archives.fr/), combined with documentary data (Rambaud \& Vincienne 1964, Jail 1969). Numbers of cattle and sheep + goats in the upper Maurienne Valley were obtained from the Archives Départementales de Savoie, from the agricultural census (recensements généraux agricoles) and from the literature (Rambaud \& Vincienne 1964, Jail 1969).

Finally, we used redundancy analysis (RDA), a constrained ordination method (Rao 1964), to investigate the proportion of variability explained by predictor variables relating to anthropogenic influences and historical forest cover, and their correlation with LBM outbreak frequency and severity. A $6 \times 9$ matrix was created, associating the 6 time periods classified by the maps (see Table 2) with the corresponding historical predictors (i.e. inhabitant or animal numbers, forest cover or structure) and LBM variables (i.e. outbreak frequency or severity). RDA is a technique used for 2 sets of variables, one set being dependent on the other. Its aim is to maximize the explained variance of the dependent variables by a linear combination of the explanatory variables. The analysis was performed using the package XLSTAT 2010 (Microsoft).

\section{RESULTS}

\subsection{LBM outbreak characteristics: frequency, population and individual severity}

A high EPS value for all sites $(>0.85)$ indicates that TRW chronologies were representative of radial growth variation of the whole tree population (Wigley et al. 1984). However, the mean larch TRW chronology (Fig. 2a) revealed several ring width reductions, interpreted as the consequence of LBM outbreaks because these depressions did not correspond to similar events in the pine non-host reference chronology (Fig. 2b). We thus found a low correlation between the TRW of the 2 species $(r=0.32, p<0.05)$. Between 1700 and 2010, 23 LBM outbreaks (orange crosses, Fig. 2a) were detected. The date and characteristics of each event are summarized in Table 1, which also highlights the data common to our reconstructed LBM events and the historical evidence. The same method was applied to the pine tree-ring series to detect any LBM attacks on this species and to identify any climate effect in the growth reduction of both species. The length of each larch outbreak varied between 2 and $5 \mathrm{yr}$ and the events occurred with a mean \pm SD LBM interval of $13 \pm 5$ yr. That said, almost half of the LBM events (44\%) occurred during the 19th century. Only 6 events were identified within the pine series (green crosses, Fig. 2b), characterized by a short duration and a more limited number of affected trees and less growth reduction as compared with larch (Table 1). The comparison between our reconstruction of LBM outbreaks and the historical defoliation events observed during the period 18002000 in the same area (Baltensweiler \& Rubli 1999) showed $60 \%$ agreement between the reconstructed and observed events (common events: 1813, 1819, 1854-1856, 1953, 1961 and 1971).

The 310-yr reconstructed outbreak history showed a clear change in the frequency (outbreaks $100 \mathrm{yr}^{-1}$ ) between 1810 and 1850, when the frequency reached its highest value (Fig. 2c), but no cyclic recurrence of outbreaks was found. Another period of elevated frequency was recorded between 1730 and 1750, while during the entire 18th century the frequency distribution was characterized by periodic LBM events with significant wavelengths of 8 and $17 \mathrm{yr}$ (Fig. 2c, inset). Together, the 8- and 17-yr cycles accounted for almost $60 \%$ of variance during this time period. From 1860 to 2010, a slight decrease in the outbreak frequency was observed, and no significant wavelength was recorded in the LBM events.

Outbreak severity can be measured at the population level and expressed in terms of the percentage of affected trees (Fig. 2d), or at the individual level, expressed as radial growth reduction (Fig. 2e). The severity pattern at both population and individual levels followed a similar trend to the frequency, with 3 statistically significant switches over the same time period, although the exact dates of maxima were not synchronous. However, the percentage of affected trees (Fig. 2d) was higher during the first half of the 18th century than during the period of maximal outbreak frequency from 1810 to 1850 . During the 19th century, the period between 1815 and 1835 appears

Fig. 2. Reconstruction of larch budmoth (LBM) outbreak regime. (a) Mean Larix decidua tree-ring indexed chronology (orange line) and number of samples (black line). Orange crosses indicate LBM outbreaks. (b) Pinus cembra tree-ring width (TRW) chronology (green line) and number of samples (black line). Green crosses indicate LBM outbreaks. (c) Frequency of LBM outbreaks, (d) percentage of affected trees (population severity) and (e) percentage of growth reduction (individual severity) transformed and fitted by LOWESS smoothing with a 50 yr time window. Dashed lines: $99 \%$ confidence range; the mean value of each distribution $(\mu)$ and the standard deviation $(2 \sigma)$ are reported; gray shading: changes in outbreak characteristics. The inset in (c) shows singular spectral analysis over the period 1700-1799; the periods are given in years for each significant peak 
응
을
음
른
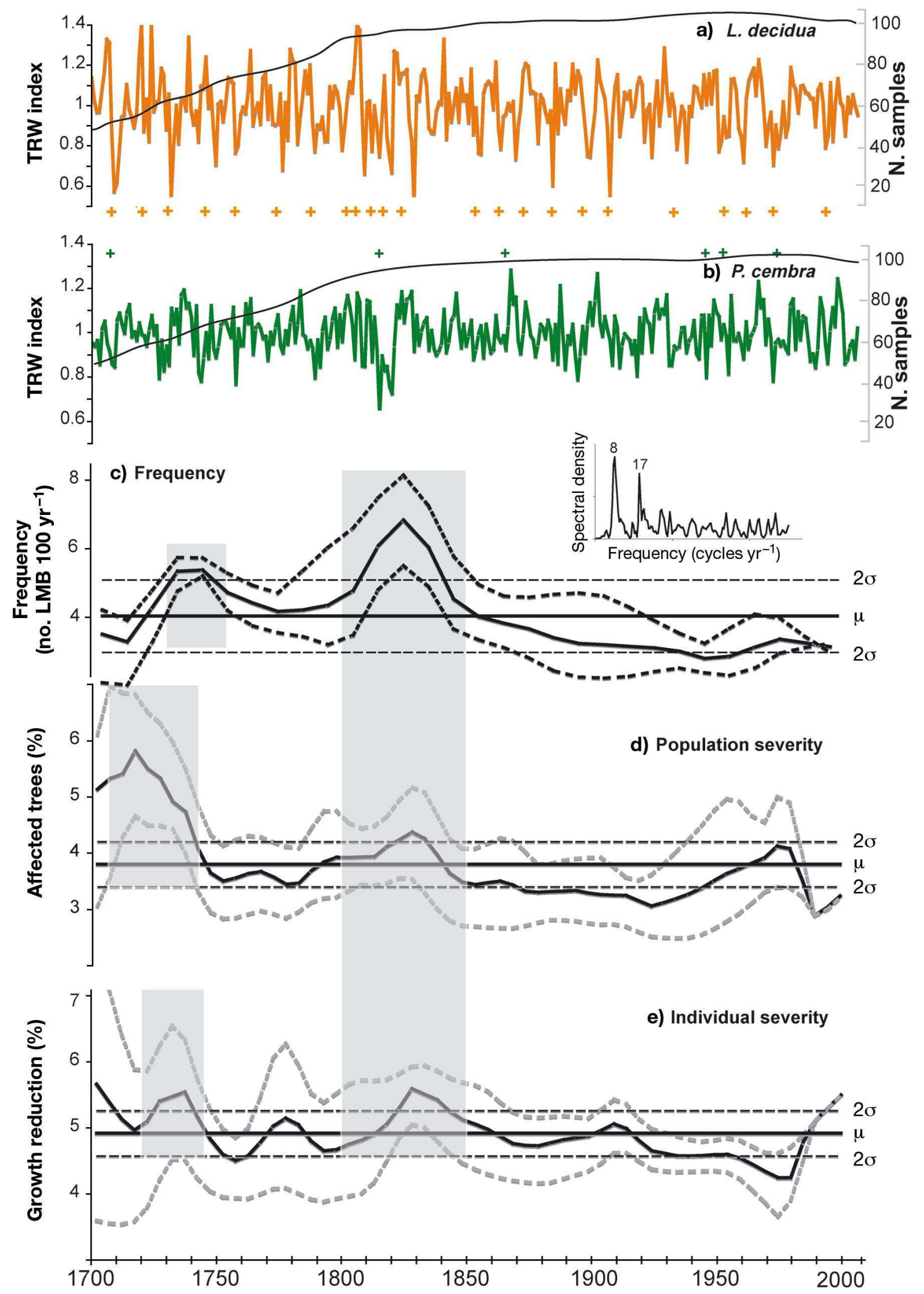
Table 1. Characteristics of reconstructed larch budmoth (LBM) attacks on Larix decida and Pinus cembra. The percentage of growth reduction is calculated as follows: $100-$ (growth in the first year of the outbreaks/growth in the previous year) $\times 100$

\begin{tabular}{|c|c|c|c|c|}
\hline No. outbreaks & $\begin{array}{l}\text { Initial } \\
\text { year }\end{array}$ & $\begin{array}{l}\text { Length } \\
\text { (yr) }\end{array}$ & $\begin{array}{l}\text { Affected } \\
\text { trees (\%) }\end{array}$ & $\begin{array}{c}\text { Growth } \\
\text { reduction (\%) }\end{array}$ \\
\hline \multicolumn{5}{|l|}{ Larix decidua } \\
\hline 1 & 1708 & 2 & 45 & 78 \\
\hline 2 & 1721 & 4 & 32 & 76 \\
\hline 3 & 1730 & 2 & 34 & 75 \\
\hline 4 & 1747 & 3 & 25 & 60 \\
\hline 5 & 1758 & 4 & 33 & 60 \\
\hline 6 & 1775 & 3 & 28 & 75 \\
\hline 7 & 1789 & 4 & 39 & 50 \\
\hline 8 & 1801 & 2 & 30 & 85 \\
\hline 9 & 1809 & 4 & 37 & 98 \\
\hline 10 & $1813^{\mathrm{a}}$ & 2 & 30 & 95 \\
\hline 11 & $1819^{a}$ & 2 & 27 & 75 \\
\hline 12 & 1829 & 2 & 35 & 96 \\
\hline 13 & $1854^{\mathrm{a}}$ & 4 & 30 & 60 \\
\hline 14 & 1864 & 4 & 25 & 68 \\
\hline 15 & 1877 & 3 & 25 & 65 \\
\hline 16 & 1884 & 5 & 28 & 69 \\
\hline 17 & 1898 & 5 & 25 & 85 \\
\hline 18 & 1908 & 3 & 30 & 90 \\
\hline 19 & $1933^{\mathrm{a}}$ & 4 & 25 & 60 \\
\hline 20 & $1953^{a}$ & 2 & 39 & 50 \\
\hline 21 & $1961^{\mathrm{a}}$ & 3 & 25 & 40 \\
\hline 22 & $1975^{\mathrm{a}}$ & 5 & 30 & 60 \\
\hline 23 & 1996 & 3 & 25 & 75 \\
\hline \multicolumn{5}{|l|}{ Pinus cembra } \\
\hline 1 & 1708 & 2 & 25 & 35 \\
\hline 2 & 1816 & 1 & 25 & 37 \\
\hline 3 & 1866 & 1 & 27 & 30 \\
\hline 4 & 1944 & 1 & 26 & 33 \\
\hline 5 & 1953 & 2 & 25 & 28 \\
\hline 6 & 1976 & 1 & 27 & 31 \\
\hline
\end{tabular}

${ }^{a}$ Correspondence between reconstructed LBM events and those observed during the period $1800-2000$ by Baltensweiler \& Rubli (1999)

to have been the most important for both frequency (Fig. 2c) and the 2 components of severity (Fig. 2d,e). The trends for both population and individual severities were generally lower than the average value recorded for the entire record, particularly during the 1850-1940 and 1950-1980 time periods, when the trends were within the $<2 \sigma$ range.

\subsection{Forest recruitment and land uses}

Forest dynamics were assessed through tree recruitment data (Fig. 3a), showing that over the past $310 \mathrm{yr}$ the forest has experienced almost continuous regeneration. Larch largely dominated the recruitment $(58 \pm 10 \%)$ during the 18th and 19th centuries,

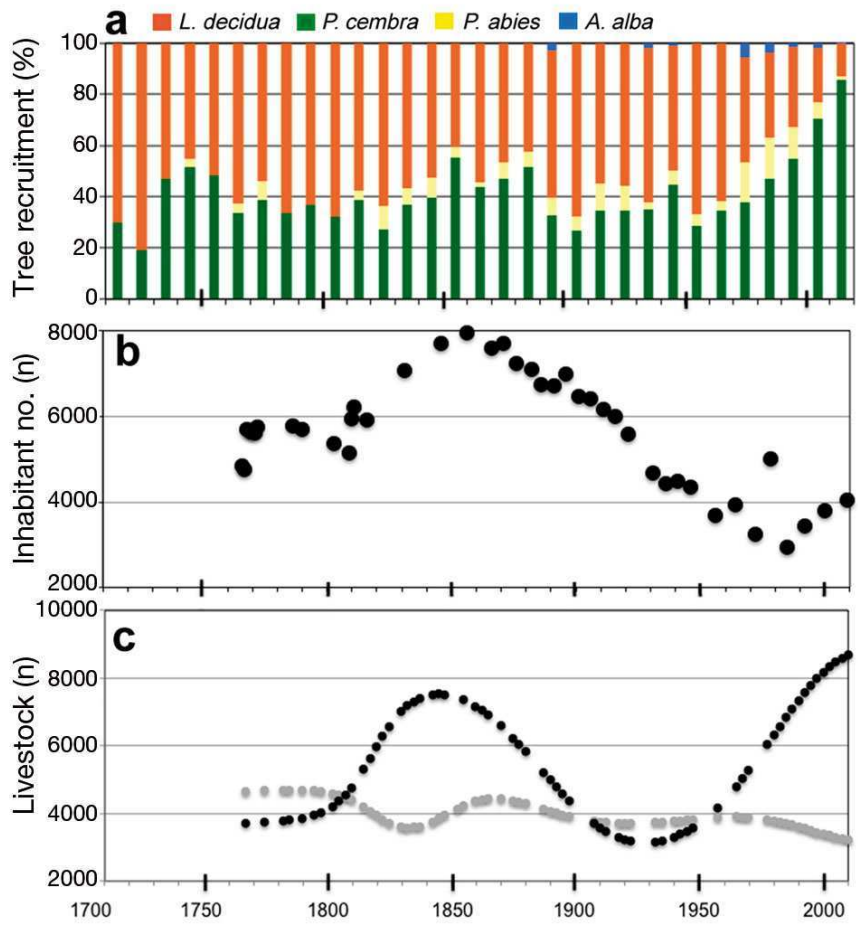

Fig. 3. (a) Relative recruitment per decade and per canopy species for Larix decidua (orange), Pinus cembra (green), Abies alba (blue) and Picea abies (yellow). (b) Number of local human inhabitants in the municipalities surrounding the study sites. (c) Number of resident sheep and goats (black circles) and cattle (gray circles)

while the 20th century was characterized by an increase in pine, spruce (Picea abies [L.] Karst) and silver fir (Abies alba Mill.) recruitment and a decrease in larch starting in the 1940s and peaking after 1960, when pine represented $59 \pm 19 \%$ of the recruitment on average, and larch only $28 \pm 11 \%$. Based on the Kingdom of Savoy tax census from the 18th to 19th centuries and on the French census during the 19th to 20th centuries, the total inhabitant numbers in the 10 municipalities of the upper Maurienne Valley increased from 1800 and reached a maximum in 1846 . After the mid-19th century, the human population started to decrease gradually until 1975, when the lowest population was recorded (2931 inhabitants), i.e. almost $65 \%$ less than the maximum recorded in 1846 (Fig. 3b). Until the 1950s, the inhabitant numbers correlated well with the number of domestic animals that were the economic basis of the mountain society, in particular with the total number of sheep and goats (Fig. 3c). However, during the 1980s and 1990s, the local sheep economy became more pronounced in the area, thanks to economic funding from the French government and EU agricultural policies, which supported the breeding of rare sheep and coincided with the increase in pine recruitment. 
The total cover of subalpine forests was estimated using the 6 historical maps (Table 2). We observed a decrease of $38 \%$ (from 35.6 to $22.2 \mathrm{~km}^{2}$ ) between the 18th (Mappe Sarde) and the late 19th centuries (Premier cadastre français), and a huge increase of $136 \%$ (22.2 to $52.5 \mathrm{~km}^{2}$ ) in forest cover during the 20th century.

The relationships between LBM frequency and severity and anthropogenic factors were assessed through RDA (Fig. 4). The first and second axes accounted for 83.7 and $15.8 \%$ of the total variance, respectively. The LBM frequency (LBMf) and the

Table 2. Source and characteristics of the historical maps used for forest cover reconstruction. Forest cover is expressed as mean $\pm \mathrm{SD}$

\begin{tabular}{|lccc|}
\hline Source & Years & Scale & $\begin{array}{c}\text { Forest cover } \\
\left(\mathrm{km}^{2}\right)\end{array}$ \\
\hline Mappe Sarde & $1728-1738$ & $1: 2372$ & $35.6 \pm 3.4$ \\
Premier cadastre & $1850-1895$ & $1: 500 ;$ & $22.2 \pm 3.1$ \\
français & & $1: 50000$ & \\
Cadastre rénové & $1927-1939$ & $1: 20000$ & $35.2 \pm 2.9$ \\
Phytosociological map & 1996 & $1: 50000$ & $36.8 \pm 1.7$ \\
Corine Land Cover & 2000 & $1: 100000$ & $50.1 \pm 1.6$ \\
BD topo IGN & 2010 & $1: 25000$ & $52.5 \pm 1.3$ \\
aSee http://ddaf73.agriculture.gouv.fr/Observatoire/ & \\
\hline
\end{tabular}

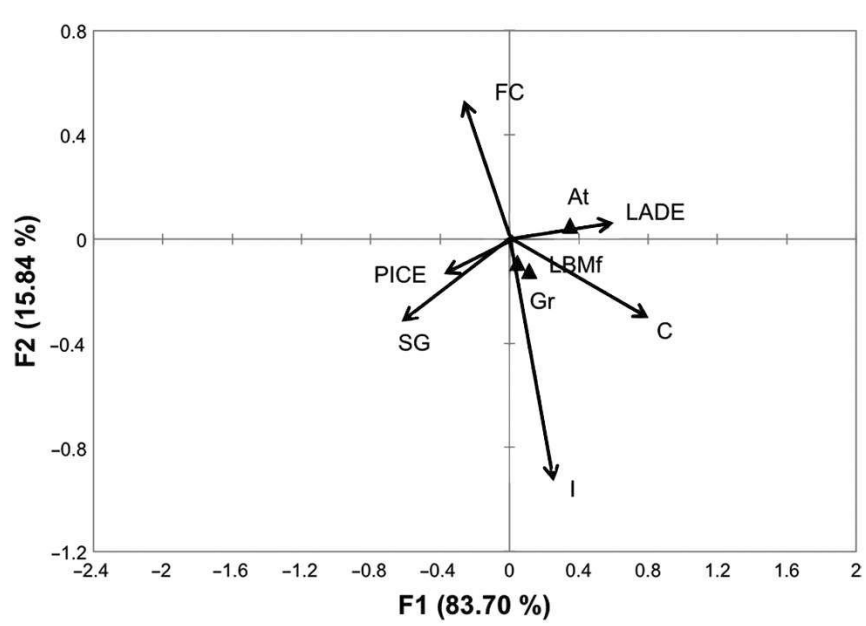

Fig. 4. Redundancy analysis (RDA) of larch budmoth (LBM) outbreak frequency and severity in relation to anthropogenic factors and historical land uses. The first and second axes are displayed and they accounted for $99.5 \%$ of the total variance. Arrows represent the number of inhabitants (I), number of cattle (C), number of sheep and goats (SG), forest cover (FC), percentage of Larix decidua (LADE) and percentage of Pinus cembra (PICE). Triangles: LBM frequency (LBMf), the percentage of growth reduction $(\mathrm{Gr})$ and the percentage of affected trees (At) percentage of growth reduction (Gr) were positively associated with the number of inhabitants (I) and number of cattle (C), while an opposite cluster was revealed with forest cover (FC). The percentage of affected trees (At) was positively linked to the percentage of larch (LADE) and negatively associated with pine (PICE), the latter related to the number of sheep and goats (SG).

\subsection{Radial growth and climatic interaction}

SEA applied on larch TRW series (Fig. 5a) showed a significant tree growth decrease during outbreak years (given as 0 in Fig. 5) and in the 3 following years, whereas the relationship was highly positive during the $3 \mathrm{yr}$ prior to the LBM outbreak. For pine, in contrast, there were no significant departures in tree-ring growth with the SEA over the 7-yr window before, during or after outbreaks, although a slight TRW decrease was recorded during the year after each reconstructed event (Fig. 5b).

The correlation between TRW of both tree species with climate features (Fig. S4 in the Supplement at www.int-res.com/articles/suppl/c062p001_supp.pdf), as well as the $40 \mathrm{yr}$ running correlations (data not shown) performed to test temporal stability of climategrowth relationships, showed no correlation with precipitation, and a correlation only with summer temperature (larch, $\mathrm{r}=0.30, \mathrm{p}<0.05$; pine, $\mathrm{r}=0.49, \mathrm{p}<$ 0.01), and no temporal shift was observed. Moreover, SEA between TRW and climate features revealed that there was no linkage between LBM outbreaks, as reconstructed from larch, with the instrumental temper-

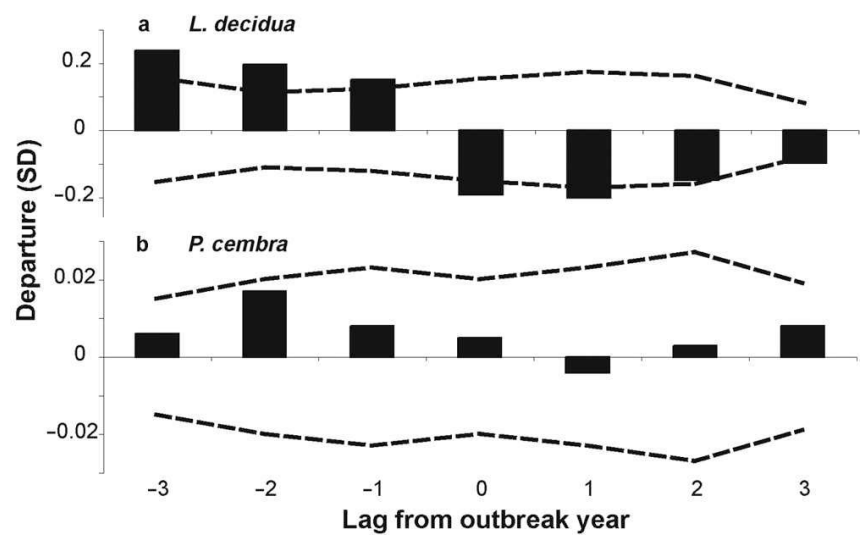

Fig. 5. Relationship between local tree-ring width index and larch budmoth outbreaks determined by superposed epoch analysis for (a) larch Larix decidua and (b) Arolla pine Pinus cembra stand chronologies. Bars represent deviation from normal conditions based on 1000 simulations. The $99 \%$ confidence limits are plotted as dashed lines 

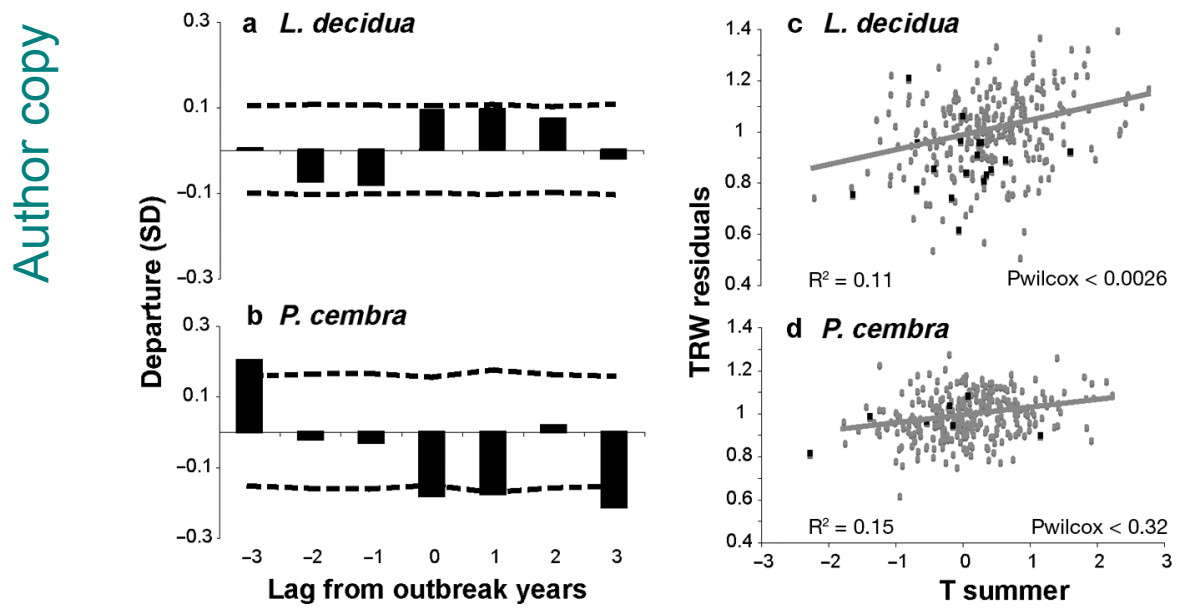

Fig. 6. (a,b) Mean departures for the summer temperature index for years before, during and after outbreak events for (a) larch Larix decidua and (b) Arolla pine Pinus cembra. The $99 \%$ confidence limit is plotted as a dashed line. (c,d) Analysis of residuals of tree-ring width (TRW) for (c) L. decidua and (d) P. cembra with summer temperatures for the period 1900-2010. Black squares: larch budmoth events. p-values <0.05 (Wilcoxon-Mann-Whitney rank sum test) indicate significant differences between groups

ature record (Fig. 6a), while the reconstructed outbreaks events from pine were associated with cold summer temperatures (Fig. 6b). To determine the influence of LBM outbreaks on TRW without a climate bias, we calculated the residuals between TRW of both species and summer temperature by plotting the tree-ring parameters against summer temperature and fitting them with a regression line. While for larch (Fig. 6c) the TRW residuals for LBM outbreak events are clearly outliers compared with the whole chronology ( $p<0.05)$, for pine, LBM residual TRW values are not different from the whole climate data set (Fig. 6d). Together, these results suggest there is less of an effect of climate than LBM outbreaks on larch TRW.

\section{DISCUSSION}

Forest insect outbreaks leave distinct and quantifiable signals in tree rings because defoliation significantly reduces radial growth during and after an outbreak year (Weber 1997), allowing LBM outbreak reconstruction over exceptional temporal (Esper et al. 2007) and spatial scales (Büntgen et al. 2009). The present study comprises the longest record of LBM outbreaks in the western Alps. Further, to our knowledge, it is the first study to link the effects of both climate and land-use change with insect outbreaks, providing relevant information for forest managers to counteract or mitigate the possible negative consequences on the forest ecosystems.

\subsection{LBM outbreaks and climate}

Distinctive growth depressions in the ring-width signature attributed to LBM outbreaks were found in our larch chronologies. Our reconstructed years of outbreak events were compared with previous reports (Weber 1995, 1997, Rolland et al. 2001, Nola et al. 2006, Daux et al. 2011) in order to verify the effectiveness of our LBM reconstruction. Some events recorded in our reconstruction presented a 1- or 2-yr shift in the initial date compared with other studies (Table 3). For example, Rolland et al. (2001) and Daux et al. (2011) referred to a 1811 outbreak and Nola et al. (2006) to 1810, whereas we found 2 outbreaks in 1809 and 1813, each lasting for a couple of years. Furthermore, these studies reported different numbers of outbreaks events during the 19th and the 20th centuries in comparison with our findings: Rolland et al. (2001) found 22 outbreaks from 1801 to 1987, Nola et al. (2006) found 16 from 1802 to 1996, and Daux et al. (2011) reported 12 outbreaks from 1811 to 1996 (Table 3). These apparent differences could be due to 2 factors: first, the dispersion mechanisms of this insect and the traveling velocity of the LBM waves throughout the Alps (Bjornstad et al. 2002) and, second, the statistical criteria used in our outbreak analysis were based on a very conservative approach in order to reduce errors in LBM identification. In fact, although these studies were carried out in western Alpine valleys (Maurienne, Tarentaise, Susa, Névache), each of these valleys are separated by important mountains at the north (Vanoise Massif) and the south (Thabor Massif and mounts Ambin and Cenis). However, when comparing our LBM outbreak reconstruction with historical defoliation patterns observed by Baltensweiler \& Rubli (1999) during the period 1800-2000, we have $60 \%$ agreement between the outbreaks reconstructed and the observed (Table 1).

Among the 6 events recorded within the pine chronology, only $2(1708,1953)$ matched the LBM outbreaks reconstructed from larch TRW. Furthermore, the reconstructed pine outbreaks affected a limited number of individuals and growth reduction was less pronounced. These findings indicate that LBM population activity did not significantly alter pine growth. Moreover, 3 events identified as possible outbreaks on pine, i.e. 1816, 1944 and 1976, have 
Table 3. Synthesis of larch budmoth (LBM) outbreak years on Larix decidua in the Maurienne Valley and the surroundings in the north (Tarentaise Valley) and south (Susa and Névache Valleys). X: event reported; empty cell: no reported event

\begin{tabular}{|c|c|c|c|c|}
\hline LBM year(s) & $\begin{array}{c}\text { Present } \\
\text { study } \\
\text { Maurienne }\end{array}$ & $\begin{array}{l}\text { Rolland et al. } \\
\text { (2001) Maurienne } \\
\text { and Tarentaise }\end{array}$ & $\begin{array}{l}\text { Nola et } \\
\text { al. (2006) } \\
\text { Susa }\end{array}$ & $\begin{array}{l}\text { Daux et } \\
\text { al. (2011) } \\
\text { Névache }\end{array}$ \\
\hline 1708 & $X$ & & & \\
\hline 1721 & $\mathrm{X}$ & & & \\
\hline 1730 & $\mathrm{X}$ & & & \\
\hline 1747 & $\mathrm{X}$ & & & \\
\hline 1758 & $\mathrm{X}$ & & & \\
\hline 1766 & & & $\mathrm{X}$ & \\
\hline 1775 & $\mathrm{X}$ & & $\mathrm{X}$ & \\
\hline 1789 & $\mathrm{X}$ & & & \\
\hline 1792 & & & $\mathrm{X}$ & \\
\hline 1801-1802 & 1802 & 1801 & 1802 & \\
\hline 1809-1811 & 1809 & 1811 & 1810 & 1811 \\
\hline 1813 & $\mathrm{X}$ & & & \\
\hline 1819-1820 & 1819 & 1820 & 1820 & 1819 \\
\hline 1829-1930 & 1829 & 1830 & 1829 & \\
\hline 1837-1838 & & 1838 & 1837 & \\
\hline 1846 & & $\mathrm{X}$ & X & \\
\hline 1854 & $\mathrm{X}$ & & & \\
\hline 1856-1857 & & 1857 & 1856 & 1856 \\
\hline 1864 & 1864 & & 1865 & \\
\hline 1867 & & $\mathrm{X}$ & & \\
\hline 1875 & & $\mathrm{X}$ & & \\
\hline 1877 & $\mathrm{X}$ & & & \\
\hline 1883-1884 & 1884 & 1884 & 1884 & 1883 \\
\hline 1892 & & $\mathrm{X}$ & & \\
\hline 1898-1900 & 1898 & 1901 & 1899 & 1900 \\
\hline 1908-1909 & 1908 & 1909 & 1908 & \\
\hline 1918 & & $\mathrm{X}$ & & \\
\hline 1926 & & $\mathrm{X}$ & & \\
\hline 1933 & $\mathrm{X}$ & & & \\
\hline 1935-1936 & & 1936 & 1935 & 1935 \\
\hline 1943 & & & & $\mathrm{X}$ \\
\hline 1945 & & $\mathrm{X}$ & & \\
\hline 1953 & $\mathrm{X}$ & $\mathrm{X}$ & $\mathrm{X}$ & $\mathrm{X}$ \\
\hline 1961-1963 & 1961 & 1963 & 1962 & 1962 \\
\hline 1971-1972 & & 1972 & 1971 & 1972 \\
\hline 1975 & $\mathrm{X}$ & & & \\
\hline 1979-1980 & & 1980 & & 1979 \\
\hline 1987 & & $\mathrm{X}$ & & \\
\hline 1996 & $\mathrm{X}$ & & $\mathrm{X}$ & $\mathrm{X}$ \\
\hline
\end{tabular}

also been recognized as extreme climate years in the Alps (Beniston et al. 2007, Battipaglia et al. 2010), thus suggesting that the growth reduction recorded in the pines might not be the result of insect attacks, but may simply be the result of extreme climate years. Indeed, for pine we found no significant relationships between TRW and the outbreak occurrence using the SEA approach (Fig. 5b) and, when climate variation was removed by calculating residuals, no statistical difference between pine TRW and summer temperature was found (Fig. 6d), whereas for larch the difference remained significant (Fig. 6c). This assessment does not completely rule out the possible effect of climate stressors on LBM dynamics and outbreaks, but argues in favor of other environmental mechanisms regulating LBM outbreak dynamics, as well as the modification in vegetation cover and landscape structure triggered by land-use changes during the last few centuries.

\subsection{Variation in LBM outbreak intensity and land-use cover change}

Our reconstruction of LBM outbreaks indicates that a broad range of severities and frequencies has occurred over the last 3 centuries, and that 3 different phases (Fig. 2c) in LBM frequency follow local forest patterns and changes in human society. The first phase of the frequency distribution is characterized by periodic LBM events, with wavelengths varying between 8 and 17 yr (Fig. 2c, inset), as well as the highest number of trees affected and the most important reduction in tree growth (Fig. 2d,e) and forest regeneration mainly dominated by larch recruitment (Fig. 3a). At the beginning of the industrial era, during the first half of the 19th century, an increase in local population (Fig. 3b) and military garrisons, sent to protect the nearby boundaries between France and the Kingdom of Savoy, created a major human demand for food, firewood and timber, and grazing areas for military mules and horses. This historical process triggered (1) an increase in livestock density (mostly sheep and goats), which certainly increased the effect of grazing on subalpine forests, and (2) a preferential selection of larch for timber and firewood, excluding other species, i.e. Arolla pine, silver fir and European spruce. Furthermore, the reduction in Arolla pine cover, which occurred during the preceding Kingdom of Savoy era, had been achieved through selective tree harvesting and/or seedling/sapling suppression. People using the forest to graze their animals periodically removed the pine seedlings that were not browsed or trampled by cattle or sheep (Motta et al. 2006). All of these land uses and behavioral changes are involved in the observed changes in forest structure and composition. The general decrease in forest cover observed 
from the historical maps (Table 2) and the enhancement of the proportion of larch coincided with the increase in LBM outbreak frequency and severity (Fig. 4). Indeed, outbreaks have been shown to be more common and pronounced in areas with a more homogeneous canopy as compared with those with a mixed composition (Roland 2005). Low pine and high larch densities seemed to explain the increase in frequency and severity of LBM outbreaks recorded between the periods described in the Premier cadastre français and Cadastre rénové historical maps. Later, the observed increase in forest cover, reported in recent maps (Table 2), seems to have contributed to the establishment of new dynamics, transforming the forest shape, and hence influencing the LBM regime once again. Progressive land abandonment, which started in 1870 (Fig. 3b), but became more marked after 1950, resulted in an important recruitment of pine and other woody species including silver fir and European spruce (Fig. 3a) (Genries et al. 2009, Chauchard et al. 2010), and coincided with the decrease in LBM outbreak intensity. Indeed, while the 18th and 19th centuries were dominated by traditional agriculture, the 20th century recorded a rural mutation with a net disappearance of agricultural activities. This social change impacted the use of forest for timber, fuel wood or grazing, and thus the forest cover and the composition in favor of pine, to the detriment of larch cover.

Johnson et al. (2010) stated that the change in frequency of LBM observed in the last few centuries has been due to the elevational shifts of LBM populations in response to winter temperature fluctuations. We believe that LBM dynamics is related to the longterm changes in both climate and forestland uses. If it has been shown that higher temperatures increase LBM egg mortality (Büntgen et al. 2009), thus we hypothesize that land use should play a key role in the fragmentation and composition of the forested landscape by influencing the frequency of insect outbreaks that is itself a product of population connectivity. Forest cover decreased by $45 \%$ during the early 19th century between 1700 and $2000 \mathrm{~m}$ a.s.l., resulting in a fragmentation of the LBM habitat during the 18th century, although larch recruitment increased during the 19th century (Fig. 3a) because it was favored for several domestic uses. In contrast, the late 20th century experienced a net change in forest extent due to $136 \%$ forest expansion by tree colonization of grass parcels formerly grazed or used for hay production. However, the tree colonization in grassland as well as the recruitment in forest is mostly due to Arolla pine but not larch (Genries et al.
2009, Chauchard et al. 2010; Fig. 3a). Further, timber exploitation mostly used larch and not the other tree species. Consequently, the changes in forest composition based on pine and the current timber exploitation based on larch does not favor the development of LBM habitat. This change in forest composition despite an apparent change in forest defragmentation probably helps to explain why the late 20th century frequency of LBM outbreaks decreased since the mid-19th century and did not match the 18th century regime, which was more severe and more frequent.

It has been widely demonstrated that habitat fragmentation can have several effects on insect population dynamics (Pichancourt et al. 2006), including altering the fluctuation and speed of traveling waves (Kinezaki et al. 2003, Lecomte et al. 2004). For instance, Roland (1993) noted that outbreak frequencies of the tent caterpillar in North America were greater in highly fragmented habitats. However, results from Johnson et al. (2004) on the dynamics of LBM showed that when the level of forest fragmentation surpassed an upper threshold, the insect outbreaks in those highly fragmented habitats were less frequent. While the forest in the Maurienne Valley is currently less fragmented than in the previous centuries, the progressive reduction in larch regeneration since the 1950s is strongly linked to a decrease in LBM frequency.

Our findings indicate that, without ignoring the role of climate, the changes in LBM frequencies over the past 3 centuries coincide with the changes in local societies and the changing patterns of the subalpine landscape. The period of maximum LBM frequency and elevated individual and population severity was associated with the rise in human population levels and their highest density, the increase in grazing and larch recruitment in the valley (Fig. 4). The current reduction in the frequency and severity of LBM outbreaks is occurring during a period of rapid reforestation as a result of land-use abandonment, and is characterized by an important recruitment rate of Arolla pine that is progressively transforming canopy composition.

Although our findings are particularly relevant within a local context, they demonstrate the importance of extending historical data sources coupled with dendroecological studies to the entire Alpine arc in order to recognize and quantify the role of human impact and climate change on species distribution and forest dynamics. Indeed, understanding insect dynamics and their drivers is a prerequisite to simulating and predicting distribution patterns of their population outbreaks across space and time. 
Acknowledgements. Financial support was provided by the Centre National de la Recherche Scientifique (France) to C.C. and S.P.J.M., the Ecole Pratique des Hautes Etudes (France) to O.B., and the Operational Program of Education for Competitiveness of Ministry of Education, Youth and Sports of the Czech Republic (no. CZ.1.07/2.3.00/20.0248). This research is linked to activities conducted within the COST FP1106 'STReESS' network. We thank Sandrine Chauchard and Aurélie Genries for supporting fieldwork, and M. Walters for English editing. We warmly thank the Vanoise National Park who allowed to sample within the Orgère forest.

\section{LITERATURE CITED}

Balletti C (2000) Analytical and quantitative methods for the analysis of the geometrical content of historical cartography. Int Arch Photogramm Remote Sens 33:30-37

Baltensweiler W (1993) Why the larch bud-moth cycle collapsed in the sub-alpine larch-cembran pine forests in the year 1990 for the first time since 1850. Oecologia 94: 62-66

Baltensweiler W, Rubli D (1999) Dispersal: an important driving force of the cyclic population dynamics of the larch bud moth, Zeiraphera diniana Gn. Swiss Federal Research Institute WSL, Birmensdorf, and Paul Haupt, Berne

Baltensweiler W, Weber UM, Cherubini P (2008) Tracing the influence of larch-bud-moth insect outbreaks and weather conditions on larch tree-ring growth in Engadine (Switzerland). Oikos 117:161-172

Bartoli C (1996) Etude écologique sur les associations végétales forestières de la Haute Maurienne. Ann Sci For 23: 432-761

> Battipaglia G, Frank D, Buentgen U, Dobrovolny P, Brazdil R, Pfister C, Esper J (2010) Five centuries of Central European temperature extremes reconstructed from tree-ring density and documentary evidence. Global Planet Change 72:182-191

> Beniston M, Stephenson DB, Christensen OB, Ferro CAT and others (2007) Future extreme events in European climate: an exploration of regional climate model projections. Clim Change 81:71-95

Bernetti G (1998) Selvicoltura speciale. UTET, Turin

Biondi F, Swetnam TW (1987) Box-Jenkins models of forest interior tree-ring chronologies. Tree-Ring Bull 47:71-95

Biondi F, Waikul K (2004) DENDROCLIM2002: a C++ program for statistical calibration of climate signals in treering chronologies. Comput Geosci 30:303-311

Bjørnstad ON, Peltonen M, Liebhold AM, Baltensweiler W (2002) Waves of larch budmoth outbreaks in the European Alps. Science 298:1020-1023

Blais JR (1983) Trends in the frequency, extent and severity of spruce budworm outbreaks in eastern Canada. Can J For Res 13:539-547

Büntgen U, Frank D, Liebhold A, Johnson D and others (2009) Three centuries of insect outbreaks across the European Alps. New Phytol 182:929-941

Cappuccino N, Price PW (1995) Population dynamics: new approaches and synthesis. Academic Press, San Diego, CA

> Casty C, Wanner H, Luterbacher J, Esper J, Bohm R (2005) Temperature and precipitation variability in the European Alps since 1500. Int J Climatol 25:1855-1880
Chauchard S, Beilhe F, Denis N, Carcaillet C (2010) An increase in the upper tree-limit of silver fir (Abies alba Mill.) in the Alps since the mid-20th century: a land-use change phenomenon. For Ecol Manag 259:1406-1415

Cleveland WS (1979) Robust locally weighted regression and smoothing scatterplots. J Am Stat Assoc 74:829-836

Cook ER (1985) A time series analysis approach to tree-ring standardization. PhD dissertation, University of Arizona, Tucson, AZ

> Daux V, Edouard JL, Masson-Delmotte V, Stievenard M and others (2011) Can climate variations be inferred from tree-ring parameters and stable isotopes from Larix decidua? Juvenile effects, budmoth outbreaks, and divergence issue. Earth Planet Sci Lett 309:221-233

> Dormont L, Baltensweiler W, Choquet R, Roques A (2006) Larch- and pine-feeding host races of the larch bud moth (Zeiraphera diniana) have cyclic and synchronous population fluctuations. Oikos 115:299-307

Esper J, Buntgen U, Frank DC, Nievergelt D, Liebhold A (2007) 1200 years of regular outbreaks in alpine insects. Proc R Soc B Biol Sci 274:671-679

Fischlin A, Baltensweiler W (1979) Systems analysis of the larch bud moth system: the larch-larch bud moth relationship. Mitt Schweiz Entomol Ges 52:273-289

Genries A, Morin X, Chauchard S, Carcaillet C (2009) The function of surface fires in the dynamics and structure of a formerly grazed old subalpine forest. J Ecol 97: 728-741

Ghilani CD, Wolf PR (2006) Adjustment computations: spatial data analysis, 4 th edn. J. Wiley \& Sons, Hoboken, NJ

Guiot J (1991) The bootstrapped response function. TreeRing Bull 51:39-41

Holmes RL (1993) Computer-assisted quality control in tree ring dating and measurement. Tree-Ring Bull 43:69-78

Holtmeier FK (2003) Mountain timberlines. Ecology, patchiness and dynamics. Kluwer Academic Publishers, Dordrecht

Jail M (1969) La Haute-Maurienne. Recherches sur l'évolution et les problémes d'une cellule montagnarde intraalpine. Rev Geogr Alp 57:85-146

Johnson EA, Miyanishi K (2007) Plant disturbance ecology the process and the response. Academic Press, Amsterdam

Johnson DM, Bjornstad ON, Liebhold AM (2004) Landscape geometry and travelling waves in the larch budmoth. Ecol Lett 7:967-974

Johnson DM, Buntgen U, Frank DC, Kausrud K and others (2010) Climatic warming disrupts recurrent Alpine insect outbreaks. Proc Natl Acad Sci USA 107:20576-20581

> Kinezaki N, Kawasaki K, Takasu F, Shigesada N (2003) Modeling biological invasions into periodically fragmented environments. Theor Popul Biol 64:291-302

> Kress A, Saurer M, Buntgen U, Treydte KS, Bugmann H, Siegwolf RTW (2009) Summer temperature dependency of larch budmoth outbreaks revealed by Alpine tree-ring isotope chronologies. Oecologia 160:353-365

Lecomte J, Boudjemadi K, Sarrazin F, Cally K, Clobert J (2004) Connectivity and homogenisation of population cycles and spatial synchrony universal characteristics of forest insect populations? Popul Ecol 42:205-209

Mitchell RG (1990) Effects of prescribed fire on insect pests. In: Walstad JD, Sandberg DV, Radosevich SR (eds) Natural and prescribed fire in Pacific Northwest forests. University Press, Corvallis, OR, p 111-116

Morin H, Jardon Y, Gagnon R (2007) Relationshop between 
spruce budworm outbreaks and forest dynamics in eastern North America. In: Johnson EA, Miyanishi K (eds) Plant disturbance ecology: the process and the response. Elsevier, Amsterdam, p 555-577

Motta R, Garbarino F (2003) Stand history and its consequences for the present and future dynamic in two silver fir (Abies alba Mill.) stands in the high Pesio Valley (Piedmont, Italy). Ann Sci 60:361-370

Motta R, Nola P (2001) Growth trends and dynamics in subalpine forest stands in the Varaita Valley (Piedmont, Italy) and their relationships with human activities and global change. J Veg Sci 12:219-230

Motta R, Morales M, Nola P (2006) Human land-use, forest dynamics and tree growth at the treeline in the Western Italian Alps. Ann Sci 63:739-747

Niederoest J (2002) Landscape as a historical object: 3D reconstruction and evaluation of a relief model from the 18th century. International Archives of Photogrammetry, Remote Sensing and Spatial Information Sciences 34,5/W3

> Nola P, Morales M, Motta R, Villalba R (2006) The role of larch budmoth (Zeiraphera diniana $\mathrm{Gn}$.) on forest succession in a larch (Larix decidua Mill.) and Swiss stone pine (Pinus cembra L.) stand in the Susa Valley (Piedmont, Italy). Trees-Struct Funct 20:371-382

Paritsis J, Veblen TT, Kitzberger T (2009) Assessing dendroecological methods to reconstruct defoliator outbreaks on Nothofagus pumilio in northwestern Patagonia, Argentina. Can J For Res 39:1617-1629

Peterson D, Parker VT (1998) Ecological scale: theory and applications. Columbia University Press

Pichancourt JB, Burel F, Auger P (2006) Assessing the effect of habitat fragmentation on population dynamics: an implicit modelling approach. Ecol Model 192:543-556

Radeloff VC, Mladenoff DJ, Boyce MS (2000) The changing relation of landscape patterns and jack pine budworm populations during an outbreak. Oikos 90:417-430

Rambaud P, Vincienne M (1964) Les transformations d'une société rurale. La Maurienne (1561-1962). Armand Colin, Paris

Rao CR (1964) The use and interpretation of principal component analysis in applied research. Sankhya. Indian J Stat 24:329-358

Risch AC, Nagel LM, Schutz M, Krusi BO, Kienast F, Bugmann H (2003) Structure and long-term development of subalpine Pinus montana Miller and Pinus cembra L. forests in the Central European Alps. Forstwiss Centbl 122:219-230

Roland J (1993) Large-scale forest fragmentation increases the duration of tent caterpillar outbreaks. Oecologia 93: 25-30

Roland J (2005) Are the 'seeds' of spatial variation in cyclic dynamics apparent in spatially-replicated short timeseries? An example from the forest tent caterpillar. Ann Zool Fenn 42:397-407

Rolland C, Baltensweiler W, Petitcolas V (2001) The potential for using Larix decidua ring widths in reconstructions

Editorial responsibility: Nils Chr. Stenseth, Oslo, Norway of larch budmoth (Zeiraphera diniana) outbreak history: dendrochronological estimates compared with insect surveys. Trees-Struct Funct 15:414-424

> Sala OE, Chapin FS, Armesto JJ, Berlow E and others (2000) Biodiversity-global biodiversity scenarios for the year 2100. Science 287:1770-1774

Schweingruber F (1988) Tree rings. Basics and applications of dendrochronology. Springer, Dordrecht

Simard M, Powell EN, Raffa KF, Turner MG (2012) What explains landscape patterns of tree mortality caused by bark beetle outbreaks in Greater Yellowstone? Glob Ecol Biogeogr 21:556-567

Speer JH, Swetnam TW, Wickman BE, Youngblood A (2001) Changes in pandora moth outbreak dynamics during the past 622 years. Ecology 82:679-697

Swetnam TW, Betancourt JL (1990) Fire-Southern Oscillation relations in the Southwestern United States. Science 249:1017-1020

Swetnam TW, Lynch AM (1993) Multicentury, regional-scale patterns of western spruce budworm outbreaks. Ecol Monogr 63:399-424

- Tasser E, Ruffini FV, Tappeiner U (2009) An integrative approach for analysing landscape dynamics in diverse cultivated and natural mountain areas. Landscape Ecol 24:611-628

Thomson AJ, Shepherd RF, Harris JWE, Silversides RH (1984) Relating weather to outbreaks of western spruce budworm, Choristoneura occidentalis (Lepidoptera: Tortricidae) in British Columbia. Can Entomol 116:375-381

$>$ Turchin P, Wood SN, Ellner SP, Kendall BE and others (2003) Dynamical effects of plant quality and parasitism on population cycles of larch budmoth. Ecology 84:1207-1214

- Vautard R, Ghil M (1989) Singular spectrum analysis in nonlinear dynamics, with applications to paleoclimatic time series. Physica D 35:395-424

- Watt AS (1947) Pattern and process in the plant community. J Ecol 35:1-22

Weber UM (1995) Ecological pattern of larch budmoth (Zeiraphera diniana) outbreaks in the central Swiss Alps. Dendrochronologia 13:11-31

Weber UM (1997) Dendroecological reconstruction and interpretation of larch budmoth (Zeiraphera diniana) outbreaks in two central alpine valleys of Switzerland from 1470-1990. Trees-Structure Function 11:277-290

White PS, Pickett STA (1985) Natural dysturbance and patch dynamics: an introduction. In: Pickett STA, White PS (eds) The ecology of natural disturbance and patch dynamics. Academic Press, New York, NY, p 3-13

Wigley TML, Briffa KR, Jones PD (1984) On the average value of correlated time series with application in dendroclimatology and hydrometereology. J Clim Appl Meteorol 23:201-221

> Wood DM, Parry D, Yanai RD, Pitel NE (2010) Forest fragmentation and duration of forest tent caterpillar (Malacosoma disstria Hubner) outbreaks in northern hardwood forests. For Ecol Manag 260:1193-1197

Submitted: January 3, 2014; Accepted: July 7, 2014

Proofs received from author(s): October 9, 2014 